\title{
A New Genus of the Actinomycetales-Intrasporangium gen.nov.
}

\author{
L. V. KALAKOUTSKII, IRENE P. KIRILLOVA \\ AND N. A. KRASSILNIKOV \\ Institute of Microbiology, U.S.S.R. Academy of Science, Moscow, U.S.S.R.
}

(Accepted for publication 2 February 1967)

\section{SUMMARY}

A new species and genus of the Actinomycetales is described, for which the name Intrasporangium calvum is proposed. The organism is a typical actinomycete, producing branching mycelium $0.4-1.2 \mu$ in diam. which has a definite tendency to fragment. It is characteristic for the organism to produce sporangia intercalary in the mycelial hyphae. The sporangiospores are non-motile. This new genus is proposed to be a member of the family Actinoplanaceae.

\section{INTRODUCTION}

Actinomycetes which form sporangia were first described in detail by Couch (1950, $1955,1963)$. These are now widely recognized as a rather distinct group of the Actinomycetales (Bergey's Manual, 1957; Waksman, 1959; Kalakoutskii, 1965; Krassilnikov \& Kalakoutskii, 1965; Lechevalier \& Lechevalier, 1965). The Actinoplanaceae are at present subdivided according to whether or not the sporangiospores are motile, as well as by the shape of the sporangium. Sporangia are produced by the members of this family on the tips of the sporangiophores. The formation of sporangia in a strain of the genus Actinoplanes was studied in some detail by ultra-thin sections by Lechevalier \& Holbert (1965).

The present paper describes a type of actinomycete which produces sporangia which are intercalary in the mycelial hyphae. The name proposed for the new genus is Intrasporangium and the type species I. calvum. One strain has so far been isolated. It is deposited as strain no. 7 KIP in the culture collection of the Institute of Microbiology, U.S.S.R. Academy of Science, Moscow, U.S.S.R., and in the culture collection of the All-Union Research Institute for Antibiotics, Moscow, U.S.S.R.

\section{METHODS}

Media. The composition of the media used which are not given here can be found in the following: Waksman (1961); Biology of Individual Groups of Antibiotic-producing Actinomycetes (1961); Lechevalier \& Lechevalier (1957); Lechevalier, Solotorovsky \& McDurmont (1961).

Wheat meal agar: wheat meal, $20 \mathrm{~g}$; dry baker's yeast, $50 \mathrm{mg}$; tap water to 11 .; pH 7.0.

Yeast peptone agar: baker's yeast, $5 \mathrm{~g}$.; peptone $5 \mathrm{~g}$.; glucose, $10 \mathrm{~g}$. ; tap water to $11 . ; \mathrm{pH} \mathrm{7.0.}$ 
Proflo glucose agar: Proflo (cottonseed meal, product of Traders Oil Mill Co., Fort Worth, Texas, U.S.A.), 5 g.; glucose, 10 g.; tap water to 11. ; pH 7.0.

Proflo starch agar: as above with starch instead of glucose.

Photographs and microscopy. Micrographs were taken through a trinocular Soviet 'MBI-6' microscope with a $36 \mathrm{~mm}$. photomicrography attachment. 'Micrat-200' high contrast film was used.

The undisturbed plate cultures were examined through $\times 20$ or $\times 40$ apochromatic objectives using a long focus 'tele-system' condenser.

For more precise examination of the mode of sporangial and spore formation, microcultures on thin agar layers sandwiched between a glass slide and a coverslip were used. In this case a water-immersion phase-contrast apochromatic objective $\times 70$ (aperture 1.23) was used. Stained smears were examined through a $\times 90$ apochromatic objective.

Disruption of sporangia and the release of spores were achieved by gently tapping and moving the coverslips of the microculture.

Motility was examined by putting drops of sterile tap water on undisturbed plate cultures and examining the colonies under a coverslip.

Electron micrographs were made by using the Elmi D-2 Zeiss electron microscope (original magnification $\times 8000$ ) and collodion-covered grids. The material was not shadowed. For further details see Kalakoutskii \& Kuznetsov (1964).

Staining when done was by the methods of Peshkoff (1955).

\section{RESULTS}

Description of Intrasporangium calvum gen.nov. sp.nov.

The organism was isolated on a meat-extract peptone agar plate from the air in a school dining room. Table 1 summarizes the results of attempts to cultivate it on other media. Meat-extract peptone agar or meat-extract peptone broth appeared to be most favourable for growth and development. These media were used throughout the work. The organism grew badly, if at all, on most of the media usually used for the cultivation of actinomycetes.

The organism grew slowly on meat-extract peptone broth or agar. The first signs of macroscopically visible growth appeared at 3-5 days of incubation at $28^{\circ}$. Microscopically, growth was evident in 1-2 days.

Fine branching mycelia $0 \cdot 4-1 \cdot 2 \mu$ in diam. were produced. Fragmentation was not apparent during the in situ examination. But even very young mycelia were easily fragmented in the process of making smears, or when a drop of water was placed on a growing colony and the latter examined under coverslip. Mycelial filaments penetrated the agar and formed compact, small (1-5 mm. diam.) colonies. No signs of aerial mycelia were visible on any of the media used, even by microscopical examination.

The colonies on meat-extract peptone agar as well as on other media where growth was evident (Table 1) were round, glistening and whitish (old colonies cream-whitish). They were rather reminiscent of bacterial colonies and those of certain Nocardia and Mycobacterium species.

Sporangia were seen beginning from 5 or 6 days of incubation at $28^{\circ}$. They were abundant at 12 days and more (P1. 1, fig. 1). Sporangia were mostly formed on the surface of agar cultures; they were less abundant in liquid cultures. 
The sporangia were formed in a peculiar manner which was characteristic for the organism. They were formed not on the tips of sporangiophores; but intercalary in the mycelial hyphae (P1. 1, fig. 2; P1. 2, figs. 10, 11, 12). Sometimes the young sporangia were reminiscent of empty bags, and continuation of the mycelial hyphae through the sporangium could be seen, especially in damaged sporangia (P1. 1, fig. 3). The content of young (4-6 days at $28^{\circ}$ ) sporangia was usually homogenous. Later on, the hyphae

\section{Table 1. Growth of Intrasporangium calvum on various media}

Growth examined at 2 and 4 weeks of incubation at $28^{\circ}$. In all cases growth was much worse than usual with the actinomycetes. Liquid media usually remained clear during growth of the organism, which formed a cottony sediment at the bottom.

\section{Media}

1 Meat-extract peptone broth

2 Meat-extract peptone $+0.5 \%$ glycerol broth

3 Meat-extract peptone $+0 \cdot 1 \%$ yeast extract broth (Difco)

4 Meat-extract peptone $+0.5 \%$ glucose broth

5 Meat-extract peptone $+0.5 \%$ soluble starch broth

6 Meat-extract peptone $+0.01 \%$ $\mathrm{Na}$ thioglycollate broth

7 Meat-extract peptone broth diluted $1 / 10$ with tap water

8 Meat-extract peptone $+10 \%$ (v/v) blood serum broth

9 Meat-extract peptone agar

10 Meat-extract peptone agar in an atmosphere containing $5 \%$ (v/v) $\mathrm{CO}_{2}$

11 Meat-extract peptone agar in an atmosphere of $90 \%(w / v)$ $\mathrm{H}_{2}+10 \%(\mathrm{w} / \mathrm{v}) \mathrm{O}_{2}$

12 Meat-extract peptone $+0.5 \%$ glycerol

13 Meat-peptone $+0.5 \%$ glucose agar

14 Meat-peptone $+0.5 \%$ soluble starch agar

15 Meat-extract peptone $+10 \%$ (v/v) blood serum agar

\begin{tabular}{|c|c|c|c|}
\hline Growth & & Media & Growth \\
\hline$+t$ & 16 & $\begin{array}{c}\text { Meat-extract peptone }+1 \% \\
\text { yeast extract agar (Difco) }\end{array}$ & ++ \\
\hline++ & 17 & $\begin{array}{l}\text { Meat-extract peptone }+ \text { glucose } \\
+ \text { blood serum + yeast extract }\end{array}$ & \\
\hline++ & 18 & $\begin{array}{l}\text { agar } \\
\text { Meat-extract peptone diluted }\end{array}$ & ++ \\
\hline++ & 19 & $\begin{array}{l}\text { 1/ } 10 \text { with tap water agar } \\
\text { Malt agar }+1 \% \mathrm{CaCO}_{3}\end{array}$ & \pm \\
\hline++ & $\begin{array}{l}20 \\
21\end{array}$ & $\begin{array}{l}\text { Rice agar } \\
\text { Oatmeal agar }\end{array}$ & $\begin{array}{l}+ \\
+\end{array}$ \\
\hline++ & 22 & $\begin{array}{l}\text { Potato agar } \\
\text { Potato plug }\end{array}$ & - \\
\hline+ & $\begin{array}{l}24 \\
25\end{array}$ & $\begin{array}{l}\text { Skimmed milk } \\
\text { Yeast glucose agar }\end{array}$ & $\overline{+}$ \\
\hline++ & 26 & Wheat meal agar & + \\
\hline$+t$ & $\begin{array}{l}27 \\
28 \\
29\end{array}$ & $\begin{array}{l}\text { Cornsteep glucose agar } \\
\text { Yeast starch agar } \\
\text { Soil extract agar }\end{array}$ & $\begin{array}{l} \pm \\
\pm \\
-\end{array}$ \\
\hline++ & $\begin{array}{l}30 \\
31 \\
32\end{array}$ & $\begin{array}{l}\text { Yeast peptone agar } \\
\text { Proflo glucose agar } \\
\text { Proflo starch agar }\end{array}$ & $\begin{array}{l}++ \\
- \\
-\end{array}$ \\
\hline++ & 33 & $\begin{array}{l}\text { Casein-hydrolysate yeast-extract } \\
\text { agar }\end{array}$ & \pm \\
\hline++ & $\begin{array}{l}34 \\
35\end{array}$ & $\begin{array}{l}\text { Glutamic acid glucose agar } \\
\text { Sauton medium agar }\end{array}$ & $\bar{t}$ \\
\hline++ & $\begin{array}{l}36 \\
37\end{array}$ & $\begin{array}{l}\text { Czapek medium agar } \\
\text { Glucose asparagine agar }\end{array}$ & - \\
\hline++ & 38 & Water agar & - \\
\hline++ & & & \\
\hline
\end{tabular}

inside a sporangium thickened (Pl. 2, figs. 10, 11) and accumulation and segregation of nuclear material occurred (P1. 1, fig. 4). Then round or oval bodies 1-2 $\mu$ diam. were formed inside the sporangium (P1. 1, fig. 5a,b). The exact sequence of formation of these bodies is difficult to follow by time-lapse photography because they are formed in different planes of focus. Mature sporangia were usually round or oval; very characteristic too were lemon-shaped sporangia. The sporangia were usually 5-15 $\mu$ diam. No significant differences were found in shape or size of sporangia that were formed intercalary or on the tips of hyphae (P1. 1, fig. 6).

In mature sporangia one to more than 20 round or oval bodies, $1-2 \mu$ diam., were 
seen (Pl. 2, fig. 7). They are usually in a state of Brownian movement inside the sporangium, which, when mature, seems to be filled with a kind of sap. This also interferes with photography. We have never seen active release of these bodies from a sporangium, though sometimes 'empty bags' could be seen among old sporangia (PI. 2, fig. 12). The round bodies from the sporangium can be released (P1. 2, fig. 8). If a sporangium is disrupted on a fresh medium, the released bodies germinate usually by one or two germ tubes (PI. 2, fig. 9). They could then serve the purpose of multiplication in this organism and be regarded as spores of dispersion. Attempts to find any signs of active motility in released spores were unsuccessful.

Staining properties. The mycelia were Gram-positive (in older cultures Gramvariable), not acid-fast. The sporangia and their contents were not stained by the Sudan Black stain for lipids. The maturing sporangia were strongly basophilic (methylene blue stain). Characteristic pictures were obtained with the $\mathrm{HCl}+\mathrm{Giemsa}$ nuclear stain (Pl. 1, fig. 4).

Physiological properties of the organism. As can be seen from the data in Table 1, the organism was rather fastidious in its nutritional requirements. Its growth seemed to depend on some substances contained in the peptone used (fermentative peptone manufactured by the meat combine in Semipalatinsk). Incubation in an atmosphere of hydrogen or at increased $\mathrm{CO}_{2}$ concentrations did not improve growth. Growth was prevented by strictly anaerobic conditions. Growth was possible between $28^{\circ}$ and $37^{\circ}$; there was no growth at $45^{\circ}$ in meat-extract peptone broth; and growth was faster at $37^{\circ}$ than at $28^{\circ}$. Nitrate was reduced to nitrite when $\mathrm{KNO}_{3}$ was added to meat-extract peptone broth. No liquefaction of gelatin occurs when the organism grew on meatextract peptone gelatin.

Tests for antibiotic properties of the organism. No antibiotic activity was found by using the agar block method, with Sarcina lutea, Staphylococcus aureus, Escherichia coli, Bacillus subtilis, Candida albicans, Mycobacterium sp. v-5 as test organisms.

\section{DISCUSSION}

The mode of formation of sporangia in Intrasporangium calvum here reported clearly distinguishes this organism from other members of the family Actinoplanaceae. It seems reasonable to place it in the following tentative scheme for the subdivision of Actinoplanaceae:

Actinomycetes forming sporangia:

Family Actinoplanaceae: Couch, 1950

I. Sporangia formed intercalary in the mycelial hypha. Sporangiospores non-motile Genus: Intrasporangium Kalakoutskii, Kirillova et Krassilnikov, 1966

II. Sporangia formed on the tips of sporangiophores

A. Sporangiospores motile

(a) Sporangia spheroid or irregular. Aerial mycelium usually lacking* Genus: Actinoplanes, Couch, 1950

(b) Sporangia cylindrical, bottle-shaped. Aerial mycelium usually lacking Genus: Ampulariella, Couch, 1963

(c) Sporangia spherical. Aerial mycelium present Genus: Spirillospora, Couch, 1963 
B. Sporangiospores non-motile

(a) Spheroid sporangia. Aerial mycelium present. Spores spheroid or short rods Genus: Streptosporangium Couch, 1955

(b) Sporangia irregularly shaped. Aerial mycelium usually lacking. Spores short rods.

Genus: Amorphosporangium, Couch, 1963

(c) Club-shaped sporangia formed both on the substrate mycelium and the air mycelium. Each sporangium contains only one chain of spores

Genus: Microellobosporia, $\uparrow$ Cross, Lechevalier \& Lechevalier, 1963

- A species of Actinoplanes (A. armeniacus) has been reported in which aerial conidia were produced as motile peritrichously flagellate sporangiospores (Kalakoutskii \& Kuznetsov, 1964).

+ It seems that more study is required to differentiate clearly the mode of spores formation in this genus from that in certain species of Actinomyces (Streptomyces).

In the above system, developed mainly by Couch (1963), actinomycetes with motile or non-motile sporangiospores are included. This distinction seems sharp enough to substantiate further subdivision of the family.

It has been mentioned that in colonial form and morphology Intrasporangium calvum resembles certain Nocardia species. The ability to produce motile spores by peculiar intercalary septation of the mycelium is characteristic of species of the genus Dermatophilus. In the latter case, however, no signs of a common sporangial envelope are usually visible.

A study of spore formation in sporangia of Intrasporangium calvum by electron microscopy of thin sections should be interesting. Our preliminary observations by phase-contrast microscopy suggest that it may be different from that already described in a strain of Actinoplanes by Lechevalier \& Holbert (1965). The value of examining not only the structure of reproductive structures in actinomycetes but also the manner in which they are formed has been recently discussed with special reference to the systematics of these organisms (Kalakoutskii, 1965). Attention was also recently drawn to the fact that these structures in actinomycetes closely follow those in fungi (Krassilnikov \& Kalakoutskii, 1965).

The formation of peculiar vesicles at a subterminal or terminal position on the mycelium of actinomycetes and Nocardia was mentioned by several authors (Lieske, 1921; Krassilnikov, 1938; Solovieva, Taig, Singal \& Rudaja, 1964; Mariat, 1965). Lieske described one kind of these vesicles as involution forms ('Teratologishe Wuchsformen'). Krassilnikov mentioned formation of chlamydospores. However, the most definite reference to intercalary sporangia in actinomycetes was made by Shchepkina (1940; see especially footnote 2 on p. 645), who distinguished them from chlamydospores.

The consistency and regularity of sporangial formation in Intrasporangium calvum, the rather regular shape and size of sporangia, as well as the formation of special spores inside the sporangia make it unlikely that we were dealing with involution forms. Such structures have not been described in any other genus of the Actinomycetes so far.

The authors are indebted to Mr A. A. Sokolov for help in the preparation of the electron micrographs. 


\section{REFERENCES}

Bergey's Manual of Determinative Bacteriology (1957). 7th edition. Baltimore:Williams and Wilkins Co. Biology of Individual Groups of Antibiotic-producing Actinomycetes (1961). Ed. by Ya. I. Rautenstein Moscow: Izd. AN SSSR. (In Russian.)

Couch, J. N. (1950). Actinoplanes, a new genus of the Actinomycetales. J. Elisha Mitchell Sci. Soc. $66,87$.

Couch, J. N. (1955). A new genus and family of the Actinomycetales, with a revision of the genus Actinoplanes. J. Elisha Mitchell Sci. Soc. $71,148$.

Couch, J. N. (1963). Some new genera and species of the Actinoplanaceae. J. Elisha Mitchell Sci. Soc. $79,53$.

Cross, T., Lechevalier, M. P. \& Lechevalier, H. A. (1963). A new genus of the Actinomycetales: Microellobosporia gen. nov. J. gen Microbiol. 31, 421.

KalakoutSKn, L. V. (1965). Systematics of the actinomycetes. Advances in Microbiology 2, 3. (In Russian.)

Kalakoutski, L. V. \& Kusnetsov, V. D. (1964). A new species of the Actinoplanes-A. armeniacus and some peculiarities of its mode of spore formation. Mikrobiologiya 33, 613 .

KrassiLnIKov, N. A. (1938). Ray fungi and related organisms-Actinomycetales. Moscow: Idz. AN SSSR. (In Russian.)

KRASSILNIKOV, N. A. \& KalakoutskiI, L. V. (1965). On the place of actinomycetes among lower organisms. In Biology of Individual Groups of Actinomycetes. Ed. by N. A. Krassilnikov. Moscow: Izd. Nauka. (In Russian.)

Lechevalier, H. A. \& Holbert, P. E. (1965). Electron microscopic observation of the sporangial structure of a strain of Actinoplanes. J. Bact. 89, 217.

LeCheVAlier, M. P. \& Lechevalier, H. (1957). A new genus of the Actinomycetales, Waksmania gen.nov. J. gen. Microbiol. 17, 104.

LeCheVAlIER, H.A. \& LeCheVALIER, M.P. (1965). Classification of aerobic actinomycetes based on their morphology and their chemical composition. Annls Inst. Pasteur, Paris 108, 662.

Lechevalier, H. A., Solotorovsky, M. \& McDurmont, C. J. (1961). A new genus of the Actinomycetales: Micropolyspora gen.nov. J. gen. Microbiol. 26, 11.

LIESKE, R. (1921). Morphologie und Biologie der Strahlenpilze (Aktinomyceten). Leipzig: Verlag Gebrüder Borntraeger.

MARIAT, F. (1965). Étude comparative de souches de Nocardia isolées de mycetomes. Annls Inst. Pasteur, Paris 109, 90.

Peshkoff, M. A. (1955). Cytology of Bacteria. Moscow: Izd. AN SSSR. (In Russian.)

ShCHEPKINA, T, V. (1940). Description of the cotton fibre endoparasites. Bull. Acad.Sci. USSR, Biolog. sect., 5, 643. (In Russian.)

Solovieva, N. K., Taig, M. M., Singal, E. M. \& Rudaja, S. M. (1964). Some data on micromorphology of actinomycetes. Antibiotiki 2, 115. (In Russian.)

Waksman (1959). The Actinomycetes. Vol. 1. Baltimore: Williams \& Wilkins.

Waksman (1961). The Actinomycetes. Vol. 2. Baltimore: Williams \& Wilkins.

\section{EXPLANATION OF PLATES}

\section{Plate 1}

Fig. 1. Colonies of Intrasporangium calvum growing on meat-extract peptone glycerol agar; 18 days at $28^{\circ}$. Note abundant sporangia on agar surface. $\times 300$.

Fig. 2. Six-day culture of $I$. calvum in a microculture on meat-extract peptone agar. Note the intercalary mode of sporangia formation. Phase contrast; $\times 2000$.

Fig. 3. A young sporangium with disrupted sporangial wall. Note the continuation of the hypha through the sporangium. Twelve days on meat-extract peptone agar; microculture; phase contrast; $\times 2000$.

Fig. 4. Formation of a sporangium. $\mathrm{HCl}+\mathrm{Giemsa}$ nuclear stain. Note the segregation of the nuclear material inside sporangium. Eighteen days on meat extract peptone agar; $\times 2000$.

Fig. 5. Maturing sporangium; 14 days on meat-extract peptone agar. Microculture; phase contrast; $\times 2000$. Same sporangium is photographed at different focus planes: $(a)$ to stress the intercalary position of the sporangium; $(b)$ to stress the formation of spores inside sporangium.

Fig. 6. Fourteen days on meat-extract peptone agar. Note the relative size of a sporangium formed intercalary (to the left) and the one formed on the tip of a hypha (to the right). Microculture; phase contrast; $\times 2000$. 


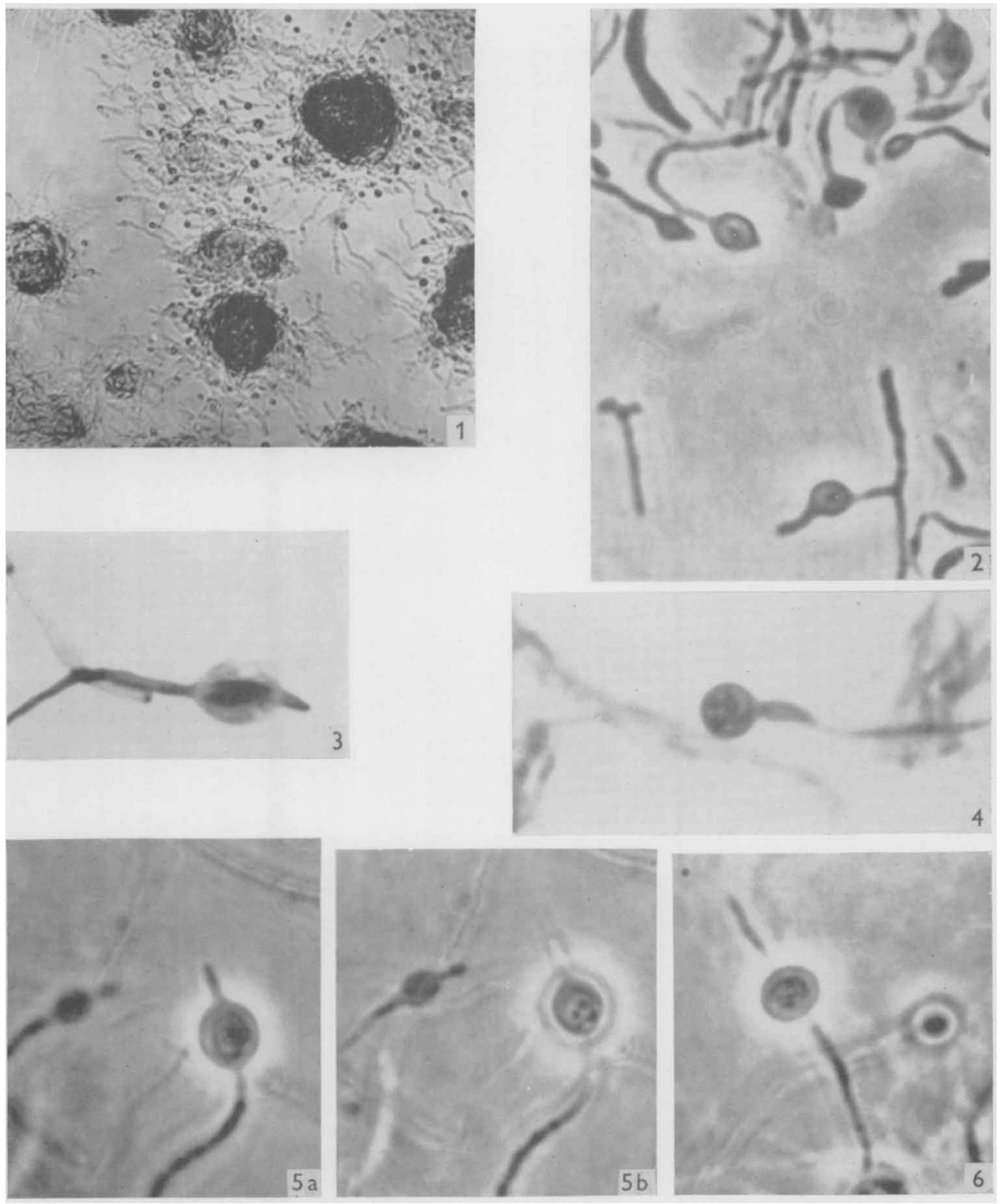



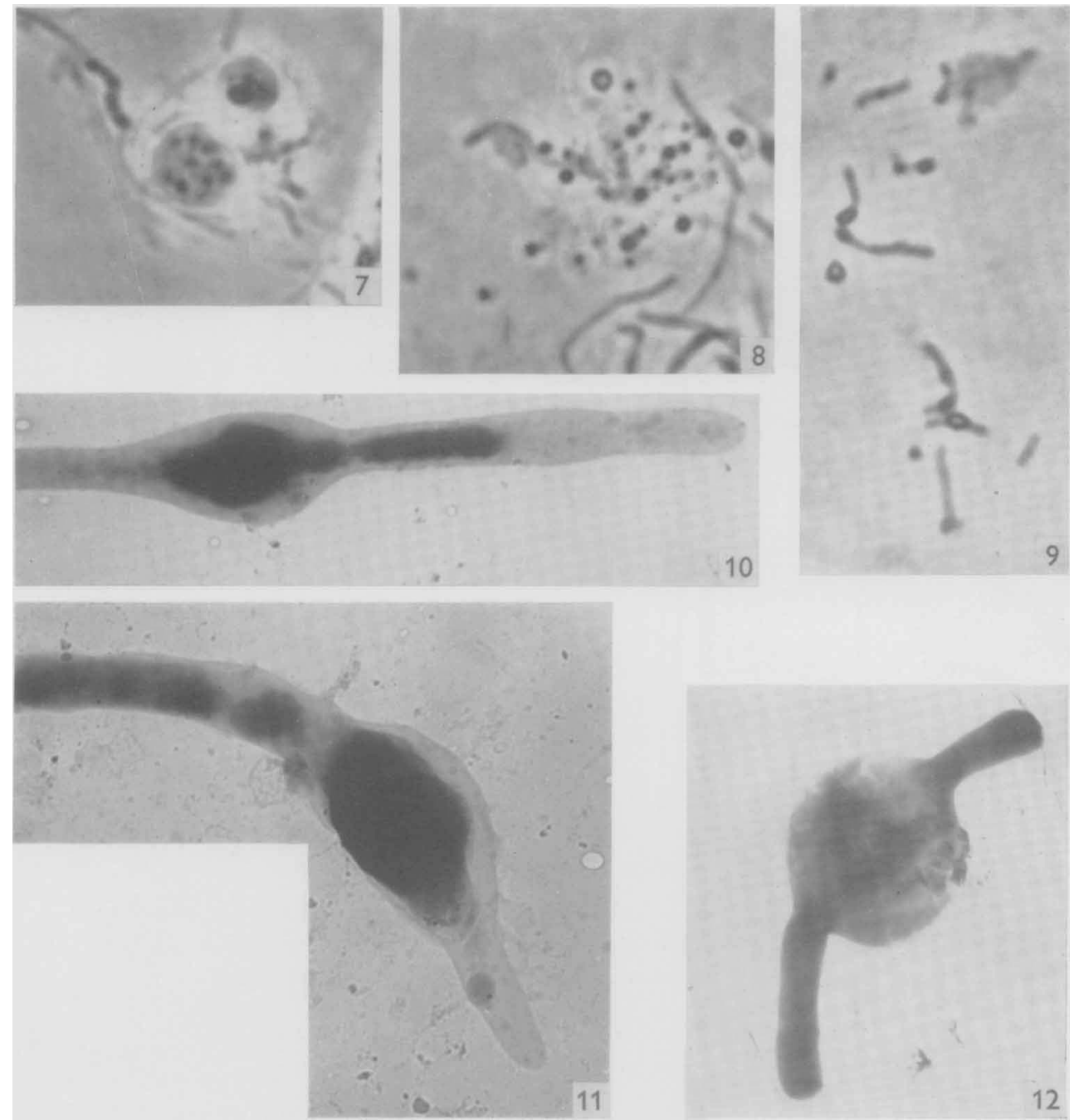

L. V. KALAKOUTSKII, I. P. KIRILLOVA AND N. A. KRASSILNIKOV 
Plate 2

Fig. 7. Mature sporangium on meat extract peptone agar. At least 10 spores are visible in a sporangium. Microculture; 38-day culture; phase contrast; $\times 2000$.

Fig. 8. A sporangium from 15-day culture on meat-extract peptone agar was disrupted and is seen to the left. Note the uneven size of the released spores. Microculture; phase contrast; $\times 2000$.

Fig. 9. Mature sporangium from a 41-day culture was disrupted (visible at the top) on a fresh meatextract peptone agar. Two days of incubation on the same agar. Note the germination of the released spores. Microculture; phase contrast; $\times 2000$.

Electron micrographs showing sporangia formation of Intrasporangium calvum. Magnification: $\times 16,000$.

Fig. 10. A hypha from a 8-day culture on meat extract peptone agar.

Fig. 11. A hypha from a 25-day culture on meat extract peptone glycerol agar.

Fig. 12. A mature disrupted sporangium from a 35-day culture on meat extract glycerol agar. 